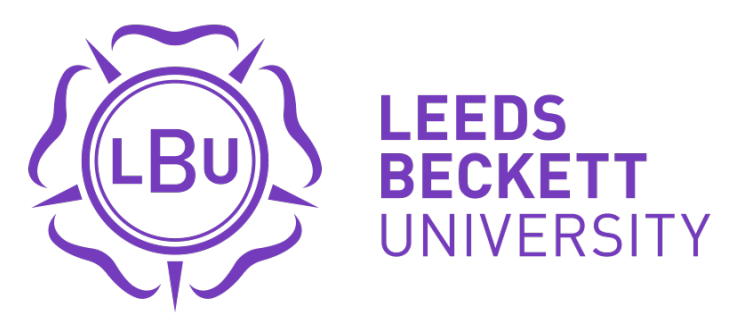

Citation:

Jones, BT and Peeroo, S and Samy, M (2018) Trialogue on Facebook pages of grocery stores: Customer engagement or customer enragement? Journal of Marketing Communications. ISSN 1352-7266 DOI: https://doi.org/10.1080/13527266.2018.1482559

Link to Leeds Beckett Repository record:

https://eprints.leedsbeckett.ac.uk/id/eprint/5047/

Document Version:

Article (Accepted Version)

This is an Accepted Manuscript of an article published by Taylor \& Francis in Journal of Marketing Communications on 11 June 2018, available online: http://www.tandfonline.com/10.1080/13527266.2018.1482559

The aim of the Leeds Beckett Repository is to provide open access to our research, as required by funder policies and permitted by publishers and copyright law.

The Leeds Beckett repository holds a wide range of publications, each of which has been checked for copyright and the relevant embargo period has been applied by the Research Services team.

We operate on a standard take-down policy. If you are the author or publisher of an output and you would like it removed from the repository, please contact us and we will investigate on a case-by-case basis.

Each thesis in the repository has been cleared where necessary by the author for third party copyright. If you would like a thesis to be removed from the repository or believe there is an issue with copyright, please contact us on openaccess@leedsbeckett.ac.uk and we will investigate on a case-by-case basis. 


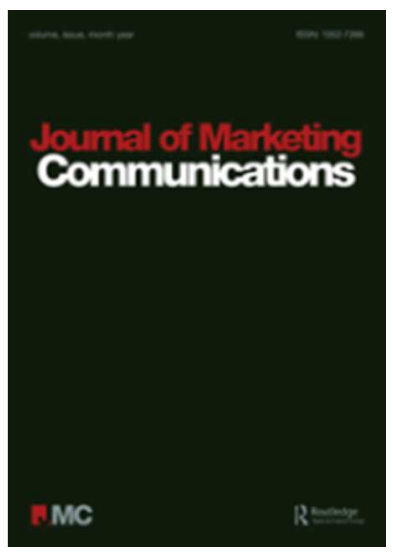

\section{Trialogue on Facebook pages of grocery stores: customer engagement or customer enragement?}

\begin{tabular}{|r|l|}
\hline Journal: & Journal of Marketing Communications \\
\hline Manuscript ID & RJMC-2017-0139.R2 \\
\hline Manuscript Type: & Original Papers \\
\hline Keywords: & $\begin{array}{l}\text { social media, customer engagement, customer empowerment, grocery } \\
\text { stores, Facebook, relationship marketing }\end{array}$ \\
\hline \multicolumn{2}{|l}{} \\
\hline
\end{tabular}

SCHOLARONE ${ }^{m}$

Manuscripts 


\title{
Trialogue on Facebook pages of grocery stores: customer engagement or customer enragement?
}

\begin{abstract}
The pervasiveness of social media is compelling businesses to review their way of managing customer experiences. Businesses use social media to interact and engage with customers. Several studies have studied why businesses have adopted social media. However, there is a dearth of research as to why customers interact with businesses on social media in the grocery sector. This paper aims to explore how and why customers react to corporate messages on Facebook pages of Tesco and Walmart. Netnography approach was adopted to gain an insight into the various ways customers engage with the grocery stores on its Facebook pages. This study reveals that social media empower customers, influence the relationships customers have with grocery stores and generate customer engagement. Findings also show that the social customer is both a curse and a blessing to Tesco and Walmart when they create or destroy value for the business. This paper contributes to knowledge by (1) uncovering how customers react to corporate and customer posts on corporate Facebook pages, (2) showing how value can be created and destroyed and (3) proposing a model illustrating how the main constructs of the study are interconnected: social media, relationship marketing, customer empowerment, and customer engagement.
\end{abstract}

Keywords - social media; customer engagement; relationship marketing; customer empowerment; grocery stores; Facebook. 

engagement or customer enragement?

\begin{abstract}
The pervasiveness of social media is compelling businesses to review their way of managing customer experiences. Businesses use social media as a marketing tool to interact and engage with customers in most industries. Several studies have studied why businesses have adopted social media. However, there is a dearth of research as to why customers interact with businesses on social media in the grocery sector. This paper aims to explore how and why customers react to corporate messages on Facebook pages of Tesco and Walmart. Netnography approach was adopted to gain an insight into the various ways customers engage with the grocery stores on its Facebook pages. This study reveals that social media empower customers, influence the relationships customers have with grocery stores and generate customer engagement. Findings also show that the social customer is both a curse and a blessing to Tesco and Walmart as they can create or destroy value for the business. This paper contributes to knowledge by (1) uncovering the various ways customers react to company and customer initiated messages posted on corporate Facebook pages, (2) showing how value can be created and destroyed and (3) proposing a model illustrating how the main constructs of the study are interconnected: social media, relationship marketing, customer empowerment, and customer engagement.
\end{abstract}

Keywords - social media; customer engagement; relationship marketing; customer empowerment; grocery stores; Facebook.

\title{
Introduction
}

The social media revolution has impacted the business world, urging companies to adapt to a new social order (Arnaboldi and Coget 2016). By providing a two-way many-to-many communication system, social media enable consumers to connect, produce, and share media content in an unprecedented manner (Daugherty and Hoffman, 2014). Social media have empowered customers by giving them a voice to spread their opinions on products and services to a very wide audience and at an incredible speed (Constantinides et al. 2008). The surge in popularity of social media platforms has multiplied and facilitated the online interactions between businesses and consumers (Goh et al. 2012). Social media offer businesses new ways to talk to consumers (Thornhill et al. 2017) and provide an online platform where customers can easily connect and interact with a brand (Lovett and Staelin 2016). Businesses can also monitor consumers' conversations and attitudes towards a brand on social media (Srinivasan et al. 2015). 

to lose the social media battle, managers have hastily integrated social media within their business strategies (Schultz and Peltier 2013). Businesses have strongly increased spending on social media, from $5.6 \%$ of marketing budgets in 2009 to a forecasted growth of $20.9 \%$ by 2021 (Moorman 2016). However, many managers are still uncertain of the opportunities and threats relating to social networks owing to the lack of knowledge of their structure and operation (Kaplan and Haenlein 2010). In today's digital era, marketers agree that social media are powerful tools, which can spread and amplify word of mouth (Shamhuyenhanzva et al. 2016). Yet most marketers ignore how to harness the power of social media (Divol et al. 2012). Customers increasingly use social networking sites (SNSs) to discuss brands, products and services, to seek or give advice, however it's still a mystery for marketers to know when, where and how to influence these online conversations (Divol et al. 2012). Governments also understand the power of marketing via social media as they support and guide local business to adapt to the new age of technology (Queensland Government)

Extant literature covers the field of social media as a marketing tool to build relationship with customers; however there is a dearth of research on the use of social media in the grocery sector though practitioners in this field are increasingly incorporating social media in their marketing strategy (Tarnowski 2011). Building relationships in self-service outlets like grocery stores have until now been challenging since there are reduced opportunities for interpersonal interactions (Keeling et al. 2011). However, social media offer the possibility to grocery stores to interact in real time with customers both inside and outside the stores (Tarnowski 2011). Therefore, it is critical for retailers within this sector to understand the opportunities and challenges offered by social media. Additionally, it is becoming very difficult for grocery stores to ignore the social media revolution since according to a survey carried out in the United Kingdom; only 15 percent of supermarket purchases were the result of traditional advertising, while 25 percent of purchases were influenced by social platforms and blogs (Snow 2012).

Research has been carried out to understand motivations of customers for interacting with businesses in the apparel sector (Anderson et al. 2014) where customers are highly involved in the purchase. These authors suggested further research to understand motivations of customers to connect with retailers in various sectors. This paper therefore aims to fill this gap by analysing the motivations of customers to interact with grocery stores, which sell mostly low involvement products by analysing responses of customers to customer and company initiated messages.

This paper aims to uncover the reasons customers engage with grocery stores on social media and to show how customer interactions on social media can be both a blessing and a curse. Focusing on Facebook postings in a retail environment this paper furthers the debate on marketing communications in and through a social media environment. This research is significant in that it brings valuable information to managers as to the expectations of customers who interact with companies via social media. This might enable companies to reengineer their social media strategies to derive more meaningful conversations, gaining higher levels of customer engagement and ultimately increasing sales and customer loyalty. In this paper, we provide a brief 
literature of social media, and customer engagement. We outline the netnographic method and present a model based on the findings of the study focusing on the challenges and opportunities that these phenomena present to retailers of the grocery sector. We then conclude, present the limitations and suggest future research directions.

\section{Literature Review}

\section{Social Media}

Social media are a collection of Internet-based applications that build on the ideological and technological foundations of Web 2.0 (Kaplan and Haenlein 2010) and mobile technology (Kietzmann et al. 2011) and they allow the creation and exchange of user-generated content (UGC). Being an open platform enabling multiway communication, social media are fast and affordable (Arnaboldi and Coget 2016). Social media empower customers and virtual communities to send and broadcast information to a global audience cheaply and instantaneously on the net (Arnaboldi and Coget 2016). Hailed as a societal revolution, social media stem from the concepts of Web 2.0 and UGC (Kizildag et al. 2017). The proliferation of UGC platforms (e.g. TripAdvisor, Yelp) and SNSs (e.g. Facebook, Twitter, Instagram) and Web 2.0 outlets (e.g. Wikis, podcasts, blogs) has assisted businesses to customise their products and services, marketing strategies, and customer relationship strategies to meet the specific needs of consumer groups (Kizildag et al. 2017). Social media have transformed the internal organisational structure of businesses by changing the way businesses communicate to the world (Kizildag et al. 2017).

\section{Customer empowerment in the social media age}

Customer empowerment is defined as a "process in which [businesses and customers] systematically interact, learn, share information and integrate resources to jointly create value" (Van Dijk et al., 2014, p. 110). The ubiquity of Web 2.0 technologies and social media has led online users to be exposed to various digital sources of information that are initiated, produced, disseminated, and consumed by online users as a way to educate one another about products, services, brands, and issues (Chauhan and Pillai 2013). Ease of access to information and the ability for customers to communicate among themselves provide them with a feeling of empowerment and a wish to play a bigger role in exchanging ideas and viewpoints with businesses (Hoyer et al., 2010). Individuals also leverage social networks and blogs to create, recommend and share information hence outspreading the reach of marketing influence (Hanna et al. 2011). Consumers in the digital age use the Internet and social media platforms to find information about products and services, to engage with the businesses they purchase from, and to connect with other customers who may provide valuable insights (Hanna et al. 2011). Traditional management methods can no longer be used with consumers on social media as they expect firms to listen to them, engage and respond accordingly (Kietzmann et al. 2011).

When brands and consumers co-create brand stories, brand owners do not have full control of their brands (Mangold and Faulds 2009) as consumer-generated brand contents can spread as quickly as those created by companies (Yan 2011). In this 
social media era, marketers find themselves at the mercy of customers who can post comments about their brands. As this new marketing paradigm evolves, there is genuine excitement about the potential of social media to add value for businesses, but also apprehension about the difficulty of seizing the full promise of this new medium (Lipsman et al. 2012).

\section{Relationship Marketing using social media}

Relationship marketing sets the company-customer relationship in the center of attention as it recognises long-term value of building relationships with customers (Bruhn 2003). Social media are used to develop and nurture brand communities (Sheth 2017). Social networking sites are increasingly being used by businesses to establish their marketing network, since social media platforms facilitate the establishment of communication and ongoing real time conversations (Coulter and Roggeveen 2012). Social media communication emanating from the business is a key element of the company's promotion mix (Mangold and Faulds 2009). The growth of social media usage among consumers provides marketers the opportunity to move forward relationships from dialogue to trialogue - in which consumers engage in meaningful conversations and relationships with one another and with the company (Porter et al., 2011). Social media offer both businesses and customers innovative ways of engaging with one another (Schivinski and Dabrowski 2014). Marketers communicate through social media to engage with loyal customers, pass on information, influence beliefs and attitudes about products and monitor the conversations to learn about their users (Brodie et al. 2013). These users consciously join groups of like-minded individuals who interact around a focal brand in brand communities (Veloutsou 2009). Brand communities are "specialized, nongeographically bound community, based on a structured set of social relationships among admirers of a brand" (Muniz and O'Guinn 2001 p. 421).

Responding to this trend, businesses are setting up online brand communities to engage with their customers (U1 Islam and Rahman 2017). With the advent of Internet technology, communities of consumers shifted online, and over 50 percent of the top 100 global brands have an online brand community (Manchanda et al. 2012). 97\% of the Fortune 500 companies used social media as a communication tool in 2013 , with $83 \%$ of these companies with an active Twitter account and $80 \%$ having a corporate Facebook page (Barnes and Lescault 2014). Because of the significant presence of potential customers on Facebook, businesses and brands invest in having a brand presence by establishing a brand community on Facebook where consumers and fans can interact with the business using the 'like', 'share' and 'comment' options (Ho 2014).

\section{Online brand communities on Facebook}

Corporate Facebook pages are online brand communities since fans who have 'liked' the page share a common interest (Pöyry et al. 2013). Research has identified that large companies use their Facebook pages to (1) promote their products and services such as launching new products and announcing sales promotions; (2) promote sponsored events for e.g. donations or sponsoring sports activities; (3) carry out surveys to get feedback from their fans; (4) make informational announcements for e.g. new opening hours or new business locations; and (5) post fun messages usually 
in a question style linked to a recent or forthcoming event (Dekay 2012). A recent study in South Africa on Generation $Z$ revealed that they updated their profile regularly and this then is advantageous for marketers to target the segment for their products or services (Duffett 2017).

Customers connect to a Facebook brand page because (1) they consume the products and services of the company, (2) they hope to get discounts and promotions, (3) they want to show to others that they like a particular brand, (4) they want to get information about the brand before others do, and (5) they wish to have access to exclusive content (Pereira et al. 2014).

Four benefits that customers gain from using social networks are: (1) social benefits by interacting with other members of the community, (2) informational benefits by accessing information about the products and services of the company, (3) hedonic benefits by enjoying and having fun on the social network for e.g. games, and finally (4) economic benefits by obtaining promotional deals. These benefits encourage community members to continue visiting and being active on social networking sites, therefore offering opportunities to firms to strengthen relationships with their customers (Park and Kim 2014).

\section{Co-creation and Co-destruction on social media platforms}

Co-creation is one of the virtues of the new age marketing enabled by social media. The evolution in connective technologies enables customers to actively participate in value creation (Agarwal and Rahman, 2017). Also, businesses provide consumers with tools and technology to participate and co-create value for themselves and other customers (Agarwal and Rahman, 2017). Value co-creation is the joint value creation activity that occurs through collaborative activities of firms and customers (BlascoArcas et al. 2014). However, for marketers who need to manage their brands, UGC and social media do not only provide opportunities but also threats (Vanden Bergh et al. 2011). Social media and UGC are a potential threat to the efforts of organisations to build, manage and protect their brands because such content is outside their immediate control (Fournier and Avery 2011). Interestingly, technologies and tools of Web 2.0 seem to ease the co-creation of value by the company and the customer (Thackeray et al. 2008).

The open-comment platform of Facebook and the anonymity offered by the Internet produce the ideal conditions for public outrage to be vented on corporate walls (Champoux et al. 2012). Furthermore, social media have empowered customers and the public by giving them a voice and weakened the position of companies by rendering them vulnerable to customer attacks, negative publicity and corporate reputation damage (Schulze Horn et al. 2015). The voice of the customer in brand communities may be a threat to the organisation if it carries a negative content (Lee et al. 2014). Social media users can generate huge waves of outrage within a short period of time when reacting to a questionable activity or statement of an organisation (Pfeffer et al. 2014). Such a phenomenon is qualified as an online firestorm, which is "the sudden discharge of large quantities of messages containing negative word of mouth and complaint behaviour against a person, company, or group in social media networks" (Pfeffer et al. 2014, 118). 

Customer engagement is believed to be the key outcome of social media campaigns (Malhotra 2012). The negative impact of posts that criticizes the service or product can be used by organizations to gauge their performance and take advantage to promote new changes and or explain their position.

\section{Customer Engagement}

In this increasingly connected world, social media channels provide new opportunities to engage customers (Alexander and Jaakkola 2016). By giving access to online content and communication through virtual tools, social media enable and facilitate consumer experiences, which may generate customer engagement with specific brands (Vivek et al. 2012). Though customer engagement has various interpretations, it is often viewed as a motivational concept, with varying intensity. It encompasses an object (i.e. a brand) and a subject (i.e. the customer) (Dessart et al. 2015), and has either a positive or negative valence (Brodie et al. 2011a; Hollbeek and Chen 2014).

Customer engagement embraces the connection that users form with businesses, following their experiences with the products, services and activities of the business (Hollbeek 2011). Vivek et al. (2012) differentiate between customerinitiated and firm initiated customer engagement. Customer-initiated engagement occurs primarily due to the internal motivational state of customers without any clear company actions. While firm-initiated customer engagement arises when businesses explicitly adopt strategies to trigger customer engagement, for example, by encouraging customers to share a video or to 'like' the brand on Facebook. Unlike conventional marketing actions, firm-initiated engagement initiatives do not aim to sell but to build relationships with customers by being interactive and prompting participative experiences (Gill et al. 2017).

van Doorn et al. (2010 p. 253) define customer engagement behaviours as "the customer's behavioral manifestations toward a brand or firm, beyond purchase, resulting from motivational drivers". Forms of engagement include posting a comment on a company's Facebook page, writing a review on TripAdvisor, interacting in a brand community, or referring a product to another customer. Other researchers argued that customer engagement also incorporates the transactional behaviour i.e. buying (Kumar et al. 2010; Pansari and Kumar 2017).

Hollebeek (2011 p. 790) defines customer brand engagement as "the level of a customer's motivational, brand-related and context dependent state of mind characterized by specific levels of cognitive, emotional and behavioural activity in direct brand interactions". In this definition of customer engagement, there are the three dimensions that have been extensively cited in the literature, namely the cognitive, emotional and behavioural perspectives (Brodie et al. 2011a; Hollbeek 2013). From a cognitive standpoint, engagement is a positive state of mind that is represented by high commitment, energy, and loyalty towards a firm (Porter et al. 2011), for e.g. the person's level of concentration or engrossment in the brand (Hollbeek 2011). From a behavioural viewpoint, engagement refers to actions toward a firm that go beyond transactions (Porter et al. 2011), for e.g. participation, vigour and interaction with the focal brand (Hollbeek 2013). From an emotional perspective, 
customer engagement may be characterised by feelings of an individual towards a brand (Vivek et al. 2012), for e.g. a customer's level of brand-related inspiration and/or pride (Hollbeek 2011). A study by Leppäniemi et al. (2016) found that customers' decisions to share information with other customers are emotional in nature since these are founded on former positive experiences with the grocery store. Hollbeek (2013) posits that the level of engagement and the resulting customer value is different depending on whether the brand is perceived as utilitarian or hedonic. Utilitarian value is increased when customers gain functional and instrumental benefits with little or no emotion involved for example when buying staple food or a washing machine. Hedonic value is experienced when a customer buys a product/service for the affective gratifications that it brings to the user for example entertainment, relaxation or escapism.

Unlike authors who have used multidimensional perspectives, van Doorn et al. (2010) focus only on the behavioural dimension of customer engagement. According to these scholars, customer engagement consists of behaviours, which go beyond transactions (van Doorn et al. 2010). Customers engage in several behaviours that boost their relationship with the brand. Behavioural manifestations do not only mean purchases, but also include other activities of the customer such as word of mouth, customer co-creation and complaining behaviour (Bijmolt et al. 2010), recommendations, helping other customers, blogging, writing reviews and even engaging in legal actions (van Doorn et al. 2010). By moving along the customer engagement cycle, value is generated both for the customer and the company. However, when organisations fail to engage customers, they have to face the potential threat of customer enragement (Leeflang et al. 2014), a situation where customers can easily become value destroyers instead of value creators for companies (Verhoef et al. 2013). This forces businesses to be increasingly reactive, or even pro-active, to avoid negative brand image consequences which in turn may lead to increased value codestruction (Beckers et al. 2017). When seeking customer engagement, managers need to consider the potential dark side of customer engagement, and be equipped to deal with customer enragement in case the engagement campaign backfires (Beckers et al. 2017).

\section{Methodology}

A netnographic study was undertaken to observe reactions of customers to company posts on Facebook pages of grocery stores. Netnography is a participant-observation method used for data collection to research the consumer behaviour of online communities and cultures present on the Internet (Kozinets 2012). Kozinets (2009) states that netnography attempts to provide understanding of a community and its interactions and communications within that community. A non-participant netnography research similar to Colliander and Wien (2013) was adopted. This netnographic research aims to analyse the reactions of customers to messages posted by grocery stores on their official Facebook pages. Moreover, netnography involves observing customers, supermarkets and hypermarkets on the Internet unobtrusively and provides a "window into naturally occurring behavior" that other marketing research tools cannot do (Kozinets 2002 p. 62). For a rigorous and reliable research approach, we have adhered to the five stages and recommended procedures: (1) making entrée, (2) data collection and analysis, (3) providing trustworthy 
interpretation, (4) research ethics, and finally (5) member checks (Kozinets et al. 2010).

For the entrée, Tesco and Walmart were chosen, as they are the major grocery stores worldwide according to the March 2013 Global Food Retail report. Additionally Tesco and Walmart adopt an international strategy and have stores in several countries. Both grocery stores have set up official Facebook pages where comments are posted in English and correspond to the criteria set by Kozinets et al. (2010) to be considered as online communities. Kozinets et al. (2010) advise to select online communities which (1) entice many individuals to actively post, (2) provide data that can be analyzed, and (3) have interactions that are relevant to the research questions. Facebook pages of Tesco and Walmart are appropriate sources of data because of their wide popularity, pervasive nature and their interactive public writing space, which allowed grocery stores to post information on their official pages for customers to read, respond and interact with.

For data collection, we downloaded conversations occurring on the official Facebook pages of Tesco and Walmart from 6 April 2014 to 6 May 2014. Similar to the study of Colliander and Wien (2013), we opted for a non-participant observation netnography and collected data during a one-month period. The data captured during a one-month period is used to convey conversations at one particular point in time. This data provides a good baseline study on which future retail netnographic studies can be built and will serve as good base for a justifiable research method for comparative analysis. Saturation of data occurred during that period (Kozinets 2002). The data were saved in word documents, the data added up to 8008 pages of texts using Arial font size 11. The data were analysed through the qualitative software, NVivo. Qualitative content analysis was used to extract themes from the datasets as recommended by Kozinets (2002). This netnographic qualitative study offers a comparative analysis of Facebook postings linked to themes identified in Tables 1 and 2. Similar to the study of Stavros et al. (2014), the unit of analysis consisted of the content of the Facebook pages of Tesco and Walmart and the coding units were the individual posts and comments by customers of these grocery stores. Constant comparative method was used to perform the qualitative data analysis (Straus \& Corbin, 1990) in order to generate insights. We first applied open coding (Miles \& Huberman, 1994) to bring meaning to the data, closely examining and comparing data for similarities and differences. Each code represented a distinct aspect of the phenomenon being studied. We then used axial coding (Miles \& Huberman, 1994) to interconnect the various categories identified in the previous stage in order to uncover any fundamental underlying trends and patterns. By interpreting the comments posted by customers on the official Facebook pages of Tesco and Walmart, we were able to identify the different ways customers reacted to company-initiated messages and customer-initiated messages.

[Insert Tables 1,2 here]

The third step of netnography is to provide trustworthy interpretation. Research is reckoned to be reasonable and trustworthy when conventional procedures of netnography are followed while collecting and analysing data (Kozinets 2002). Triangulation of data was used to enhance credibility of the study. Triangulation is achieved through the use of a large number of customers who have posted comments 
(Lincoln and Guba 1985). We also collected data from two different grocery stores to achieve site triangulation, which minimizes the impact of local factors pertaining to a specific grocery store on this research.

We adopted the ethical procedure recommended by Langer and Beckman (2005) for non-participant netnography. Comments posted on the Facebook page of Tesco and Walmart are publicly available data with no password restriction, therefore we did not need to obtain permission before using these data. However, we respected the anonymity and privacy of the participants.

Finally, the fifth step is carrying out member checks (Kozinets 2002). Member check is a technique whereby part or all of the research findings are given to the participants of the research in order to seek their comments (Lincoln and Guba 1985). However, we did not carry out member checks since this research is conducted entirely unobtrusively, and Langer and Beckman (2005) argue that in such conditions, member checks are not required.

\section{Findings and Discussions}

When customers respond to company posts or initiate conversations on the Facebook pages of Tesco and Walmart, they provide insights into the reasons why they engage with businesses on social media. Based on the themes identified in Tables 1 and 2, the reactions of customers to company-initiated messages and customer-initiated messages were identified as illustrated in Figure 1. The reactions of customers to posts on Facebook pages of Tesco and Walmart reveal that social media empower customers, influence the relationships customers have with grocery stores and generate customer engagement.

[Insert Figure 1 here]

\section{Empowered customers within the grocery sector}

While interacting with Tesco and Walmart on their official Facebook page, customers perceive that they have been empowered since they can voice out their opinions to the virtual brand community and they can also add or destroy value for the business. Cocreation of products and modification of products are not areas in which customers can add value in the grocery sector, since grocery stores do not manufacture products but only source products from their suppliers to sell to final customers. However, this study reveals that customers of Tesco and Walmart add value to the relationship by suggesting products that they would like to have, by informing the grocery stores of their needs and wants, by recommending products to their peers, and by giving advice to other customers as illustrated by the following quote:

\section{"Let's all go to tescos [sic] where allegra [sic] gets her best cloths [sic] their [sic] all half price she thinks that's nice"}

Additionally, Facebook has given a voice to the customer, which extends far beyond the circle of relatives, friends and colleagues known to the customer. By giving a voice to the customer, Facebook has empowered customers since it is easier for customers to post complaints on the page, to criticise actions of the company, than 
to call the company or write a letter of complaint. Einwiller and Steilen (2015) argue that nowadays the creation and exchange of UGC on social media sites are rather easy and effortless. Moreover, customers can observe other customers posting complaints on Facebook pages of other companies, which may make it easier for them to complain (Einwiller and Steilen 2015). Relatedly, in this study, over $65 \%$ of UGC on the Facebook page of Tesco and Walmart consisted of complaints and criticisms. When a customer posts a complaint or a criticism, it creates a snowball effect leading other customers to complain as well (Schulze Horn et al. 2015). We find that when customers of Tesco and Walmart complain on Facebook, they at times gain support from other customers. This is in line with findings of Einwiller and Steilen (2015) who say that since the complaint is publicly available on social media, the unsatisfied customer could spread his or her dissatisfaction and potentially gain support from other dissatisfied parties. So just one unhappy customer can cause a lot of harm to the corporate reputation of the organisation and customers are aware of this power they hold as illustrated below

"As a loyal employee and a loyal customer who can influence many other customers locally and via FaceBook,I [sic] hope we DO NOT carry the G.M.O. salmon that many other stores/companies are refusing to sell."

\section{Relationship building within the grocery sector}

As the modern food retail industry is booming worldwide and competition in this sector is rife, grocery retailers aim to provide superior customer value to gain customer satisfaction. To improve the satisfaction levels of customers, retailers are increasingly using social media to enrich their shopping experience (Pookulangara and. Koesler 2011). Tesco and Walmart have set up their official Facebook pages to communicate, interact and engage their customers to strengthen the relationship with them.

In this study, customers comment on the relationship they have with grocery stores by posting comments in which they have expressed satisfaction and loyalty towards Tesco and Walmart. This study reveals that customers tend to post positive comments in which they inform the company and other customers about the product or service that they have bought and how satisfied they are with the purchase as illustrated in the following quote:

"Thanks for Tesco, And all the local \& express Store's [sic], i [sic] for one appreciate polite staff and bargain prices every day thanks Tesco, I'me [sic] a BIG FAN!! [sic]"

Emotional bonding is a prerequisite to strong brand relationships (Fournier and Avery 2011). Customers of Tesco and Walmart have demonstrated their emotional commitment to the firm by posting comments in which they express their affection and attachment to the firm for e.g. by using the word 'love'. These emotional bonds therefore provide a sustainable competitive advantage (HarridgeMarch and Quinton 2009) as shown below.

"Love tescos [sic] have shopped there for the last 29yrs [sic] since I had my first son. $£ 1$ delivery slots will definitely make me shop on line!! [sic]" 
However, this study has also revealed numerous cases of dissatisfied customers who have either complained about a product or service or criticised an action of the organisation and who have vouched that they are terminating the relationship with the grocery stores as illustrated by the following quote:

"Why am I being plastered with ads from this miserable store? I hate wmart [sic]!!!!!

When retailers fail to meet expectations of customers, the relationship is broken and customers turn to competitors (Zeithaml et al. 1996). However, engaging with customers on Facebook, Tesco and Walmart can help build and maintain relationships with them.

\section{Customer Engagement within the grocery sector}

Tesco and Walmart aim to engage customers on their official Facebook pages. This study reveals that the three most extensively cited dimensions of customer engagement occur on the Facebook page of Tesco and Walmart: cognitive, emotional and behavioural. Cognitive engagement occurs at Tesco and Walmart, whenever customers post comments in which they provide information and help to other customers, or when they give advice to other customers. Another form of cognitive engagement is when customers post comments about their satisfaction and loyalty towards the stores. Customers express their satisfaction in terms of utilitarian value gained by engaging with the stores as illustrated below:

"Walmart the best store in the whole world, everything that I need is there, yeah [sic] because after looking in the other stores website comparing prices at end Walmart is the [sic] my favourite and I finished my day in Walmart."

In this statement, the customer explicitly states the utilitarian values she gains while shopping at Walmart and these utilitarian values reinforce the relationship with the grocery store. The perceived increase in utilitarian value increases the level of customer engagement of the customer who feels the need to communicate her satisfaction with the other community members. Similarly Hollbeek (2013) found that customer engagement increases utilitarian value.

Emotional engagement also occurs whenever customers post comments about their feelings and emotions. Customers use four main ways of expressing emotions on the Facebook pages of Tesco and Walmart: enthusiasm, humour, sarcasm and scepticism. Enthusiasm and humour bring hedonic value to the online community as depicted by the following quote:

"No golden egg for me but I had a lovely virtual walk around Kensington gardens, Kew Gardens, Loch Ness, Snowden and many other places. So thank you for giving me a couple of fun hours visiting places that I might not have seen xxx TY [sic]"

In this quote, the customer refers to the hedonic value she has while interacting on the Facebook page of Tesco. This finding is consistent with Hollbeek (2013) who argues that customer engagement boosts hedonic value.

While sarcasm and scepticism destroy value and even damage the image of the store as represented by the following quote: 
"So all this advert is really telling us is that you have been ripping us off for years. Thank you for that , [sic] after all Every Little Helps.....your shareholders."

Emotional engagement influences the nature of the relationship between the customer and the business (Brodie et al. 2011a).

Behavioural engagement occurs when customers request for more information, entertainment, additional incentives and when they participate by responding to posts of the stores. This study reveals that customers converse with other customers on Facebook, share advertisement, give advice to other customers, get or provide feedback to other customers, criticise other customers, help other customers, make themselves or someone else known to other customers and also provide support and encouragement to other customers as shown in Table 3.

[Insert Table 3 here]

When customers are engaged, the levels of utilitarian and hedonic value that they perceive to experience increase (Hollebeek 2013). However, findings reveal that engaged customers also post negative comments, which may harm the organisation. When this occurs, instead of engaging customers, retailers generate customer enragement (Leeflang et al. 2014). This study reveals that customers destroy value when they post comments to complain, to criticise, to provide information about competitors, to warn customers against a product/service, and to boycott a store as illustrated in Table 3. When UGC contains negative brand information, it may damage a brand (Cheong and Morrison 2008).

\section{Influence of Social Media on the Grocery Sector}

From the findings of this study, it can be concluded that the four main constructs of the study are interconnected: social media, relationship marketing, customer empowerment, and customer engagement. In the retail sector, more specifically the grocery sector, Facebook generates online customer engagement which influences the relationships customers have with Tesco and Walmart. Empowered customers use Facebook to convey their satisfaction or dissatisfaction to Tesco and Walmart as well as to the members of the community by posting comments. The interconnectedness of the constructs is depicted in Figure 2.

The model depicts the reactions of customers to messages posted on the Facebook pages of Tesco and Walmart. This study shows that customers interact with the grocery stores by 'liking', 'sharing' and 'commenting' posts on the Facebook page. By using Facebook to communicate with their customers, Tesco and Walmart compensate for the lack of interpersonal interactions within the store. Customers use the Facebook page to post queries, to complain, to criticise, and to make suggestions to the grocery stores. These interactions enhance the relationship between the two parties and give rise to the personification of the brand, a situation in which the grocery store acts as a human friend of the store's fans on Facebook.

This study also reveals that online customer engagement can either create value or destroy value. Positive online customer engagement results in co-creation of 
value, which leads to a stronger relationship between the grocery stores and their customers. While negative online customer engagement also known as online customer enragement leads to co-destruction of value, which weakens the relationship between the parties.

[Insert Figure 2 here]

In this social media era, whether the customer is satisfied or dissatisfied with the products and services of the grocery stores, the customer feels empowered as Facebook and social media offer a voice to the customer. When the customer has a positive customer experience, he/she wants to share this experience with the other members of the virtual community. Therefore, the happy and satisfied customer goes back to the Facebook page and posts a positive message, which may eventually positively influence the members of the online community. Conversely, when the customer experiences a negative outcome resulting in online customer enragement, he/she wants to share his/her experience with the other members of the virtual community. Hence, the disgruntled and angry customer posts a negative comment on the Facebook page. This customer backlash may damage the image of the grocery stores and negatively influence the other members of the online community. Online customer enragement brings co-destruction of value, which damages the relationship between the two parties.

Within the social media realm, customers feel empowered, as social media platforms have given them a voice. Whether the customers are satisfied or not, they feel empowered since they can influence the other community members. Satisfied customers post positive comments to share their positive experience, while disgruntled customers turn to Facebook to complain or to express their discontent. Therefore, it is vital that retailers understand how to harness social media to enhance the shopping experience of customers.

\section{Conclusion}

Social media have profoundly transformed the marketing landscape by providing opportunities to businesses to communicate and interact with their customers, but also challenging them by giving a voice and more power to customers. The aim of this paper was to analyse the reactions of customers on Facebook pages of Tesco and Walmart. Exploring the rich and complex world of social media through Facebook postings has served to demonstrate the shifting landscape in which marketing communications operate. This paper shows the various ways customers engage with grocery stores as illustrated in Tables 1 and 2. When customers engage positively with the grocery store, value is created and the relationship is enhanced. However, when customer enragement occurs, customers destroy value by taking actions, which harm the business such as posting complaints and criticisms or asking customers to boycott the store, thus endangering the relationships with customers. Social media have empowered customers who use Facebook to express their satisfactions or dissatisfactions on the official Facebook pages of Tesco and Walmart.

This research makes several contributions to the literature on the use of social media, more specifically Facebook in the grocery sector. However, few studies have attempted to analyse customer perceptions on the relationship building potential of 
social media. This research has analysed customer reactions to both company initiated messages and customer initiated messages on the Facebook pages of grocery stores, bridging the gap between social media literature and relationship marketing literature within the grocery sector from the customers' perspectives. This paper is unique in that it shows the interconnectedness of social media, relationship marketing, customer empowerment and customer engagement in the grocery sector. It has also identified ways customers co-create and co-destroy value in the grocery sector.

This paper has brought to light several implications for retailers. This study suggests that online brand community members want to interact with brands, and this interaction motivates them to pursue a relationship with the brand. Facebook fan pages should be designed to encourage conversations among consumers about marketing messages. Retailers should closely monitor the trialogue on social media platforms to identify the best time to participate in the conversation and respond to customers' comments to strengthen the bonds between the brand and its customers. Additionally, retailers should encourage customer co-creation on their Facebook page and should also harness customer relationship management (CRM) 2.0 by using all the information provided by customers in their comments to personalise the communication with them.

Retailers need to be aware that in this digital era, customers view social media platforms as a direct communication channel with the brand. These customers are looking for convenience and expect retailers to respond in 'real-time' to their queries. It is obvious from this study that customers perceive the official Facebook page of Tesco and Walmart as a customer service channel. Therefore retailers should attend to the queries and complaints of customers efficiently on Facebook, so that unsatisfied customers can be turned into loyal customers. As social media have made it easier for customers to complain, retailers should use this as an opportunity to positively influence the perceptions of customers by showing to them how they listen and resolve customer issues.

Retailers need to be cautious when starting conversations on social media platforms. In particular, retailers should be aware of the 'wild west' nature of social media (Tench and Jones 2015) and be ready to counteract customer enragement or any online firestorms (Pfeffer, 2013) to avoid co-destruction of value.

The limitation of the paper is related to the nature of the netnography method, which constrained the analysis to those customers who have commented on Facebook, therefore neglecting other sources such as offline customer feedback or anti brand communities. Future research might consider these other online sources where customers exchange information on brands. This paper has focused on two businesses, which are active on social media, and therefore it could be interesting to compare between a passive and an active company on social media. Another avenue for future research could be to focus on one grocery store operating in several countries to identify differences and similarities between social media communication in different country contexts. This will provide the opportunity to look at how communication is customised to specific locations i.e. the influence of place and culture.

\section{References}


Agrawal, A.K. \& Rahman, Z. 2017. "CCV Scale: Development and Validation of Customer Co-Created Value Scale in E-Services", Current Psychology, https://doi.org/10.1007/s12144-017-9639-z.

Alexander, M., and E. Jaakkola. 2016. "Customer engagement behaviours and value cocreation." In R. J. Brodie, L. D. Hollebeek, \& J. Conduit (Eds.), Customer engagement: Contemporary issues and challenges (pp. 3-20). London: Routledge.

Anderson, K., D. Knight., S. Pookulangara., B. Josiam. 2014. "Influence of hedonic and utilitarian motivations on retailer loyalty and purchase intention: a Facebook perspective." Journal of Retailing and Consumer Services, 21 (5): 773-779.

Arnaboldi, M., J.F. Coget. 2016. "Social media and business. We've been asking the wrong question" Organizational dynamics : a quarterly review of organizational behavior for professional managers, 45 (1): 47-54, http://dx.doi.org/10.1016/j.orgdyn.2015.12.006.

Baird, C. \& Parasnis, G. 2011. "From social media to social customer relationship management". Strategy \& Leadership, 39 (5): 30 - 37, https://doi.org/10.1108/10878571111161507.

Barnes, N. G., and A. M. Lescault. 2014. The 2014 Fortune 500 and Social Media: LinkedIn Dominates as Use of Newer Tools Explodes. http://www.umassd.edu/cmr/socialmediaresearch/2014fortune 500andsocialmedia/.

Beckers, S.F.M., J.F. van Doorn., and P.C.Verhoef. 2017. "Good, better, engaged? The effect of company-initiated customer engagement behavior on shareholder value." Journal of the Academy of Marketing Science. https://doi.org/10.1007/s11747-0170539-4

Bijmolt, T.H. A., P.S. H. Leeflang., F. Block, M. Eisenbeiss., B. G. S. Hardie., A. Lemmens., and P. Saffert. 2010. "Analytics for Customer Engagement." Journal of Service Research, 13 (3), pp. 341-356, doi/abs/10.1177/1094670510375603

Brodie, R. J., A. Ilic, B. Juric, and L. Hollebeek. 2013. "Consumer Engagement in a Virtual Brand Community: An Exploratory Analysis." Journal of Business Research 66 (8): 105-114, https://doi.org/10.1016/j.jbusres.2011.07.029

Brodie, R.J., L.D. Hollebeek., B. Juric., A. Ilic. 2011a. "Customer Engagement: Conceptual Domain, Fundamental Propositions, and Implications for Research." Journal of Service Research, 14 (3): 252-271, https://doi.org/ $10.1177 / 1094670511411703$.

Bruhn, M. 2003 Relationship Marketing: Management of Customer Relationships. Pearson Education, Harlow, England.

Champoux, V., J. Durgee., and L. McGlynn. 2012. "Corporate Facebook pages: when "fans" attack". Journal of Business Strategy, 33 (2): $22-30$, https://doi.org/10.1108/02756661211206717.

Chauhan, K., and A. Pillai. 2013. "Role of Content Strategy in Social Media Brand Communities: A Case of Higher Education Institutes in India." Journal of Product \& Brand Management 22 (1): 40-51, https://doi.org/10.1108/10610421311298687. 
Cheong, H., and M. Morrison. 2008. "Consumers' Reliance on Product Information and Recommendations Found in UGC." Journal Of Interactive Advertising, 8 (2): 1-29, https://doi.org/10.1080/15252019.2008.10722141.

Colleoni, E. 2013. "CSR communication strategies for organizational legitimacy in social media". Corporate Communications: An International Journal, 18 (2): 228 - 248, https://doi.org/10.1108/13563281311319508.

Colliander, J., and A. Wien. 2013. "Trash talk rebuffed: consumers' defense of companies criticized in online communities." European Journal of Marketing 47 (10): 1733-1757, DOI: 10.1108/EJM-04-2011-0191.

Constantinides, E., C. Romero., and M. Boria. 2008. "Social Media: A New Frontier for Retailers?” European Retail Research, 22: 1-28, DOI10.1007/978-3-8349-8099-1_1.

Coulter, K. S., and A. Roggeveen. 2012. "Like it or not: Consumer responses to word-ofmouth communication in on-line social networks." Management Research Review, 35 (9): 878 - 899, https://doi.org/10.1108/01409171211256587.

Crecelius, I., Einwiller, S., and Himmelreich, S. 2012. "Complaint management in social media: How companies deal with critical comments on Facebook". InECREA 2012 4th European Communication Conference Istanbul, Turkey, October pp. 24-27

Daugherty, T. and E. Hoffman. 2014. "eWOM and the importance of capturing consumer attention within social media." Journal of Marketing Communications, 20 (1-2): 82102, DOI: 10.1080/13527266.2013.797764.

Dekay, S. H. 2012. "How large companies react to negative Facebook comments." Corporate Communications: An International Journal, 17 (3): 289 - 299, https://doi.org/10.1108/13563281211253539.

Dessart, L., C. Veloutsou., and A. Morgan-Thomas. 2015. "Consumer engagement in online brand communities: A social media perspective." Journal of Product \& Brand Management, 24 (1): 1 -33, https://doi.org/10.1108/JPBM-06-2014-0635.

Divol, R., D. Edelman., and H. Sarrazin. 2012. "Demystifying Social Media." Marketing \& Sales Practice, McKinsey Quarterly. McKinsey \& Company.

Duffett, R.G. 2017. "Influence of social media marketing communications on young consumers' attitudes", Young Consumers, 18 (1): 19-39, https://doi.org/10.1108/YC07-2016-00622.

Echeverri, P., and Skålén, P. 2011. "Co-creation and co-destruction: A practice-theory based study of interactive value formation". Marketing Theory, 11 (3): 351-373, http://dx.doi.org/10.1177/1470593111408181

Einwiller, S.A and S. Steilen. 2015. "Handling complaints on social network sites - An analysis of complaints and complaint responses on Facebook and Twitter pages of large US companies." Public Relations Review, 41 (2): 195-204. http://dx.doi.org/10.1016/j.pubrev.2014.11.012

Fournier, S., and J. Avery. 2011. "The uninvited brand." Business Horizons, 54 (3): 193 207, http://dx.doi.org/10.2139/ssrn.1963056.

Gill, M., S. Sridhar., and R. Grewal. 2017. "Return on engagement Initiatives (RoEI): A Study of a Business-to-Business Mobile App." Journal of Marketing, 81(4), doi:10.1509/jm.16.0149. 
Goh, K-Y., C.S. Heng., and Z. Lin. 2012. "Social media brand community and consumer behavior: quantifying the relative impact of user- and marketer generated content", Information Systems Research, 24 (1): 88-107, https://doi.org/10.1287/isre.1120.0469.

Grönroos, C. 2012. "Creating a relationship dialogue: communication, interaction and value". The Marketing Review, 1 (1): 5-14, DOI 10.1362/1469347002523428.

Gustafsson, A., Johnson, M.D., Roos, I. 2005. "The Effects of Customer Satisfaction, Relationship Commitment Dimensions, and Triggers on Customer Retention". Journal of Marketing. 69 (4): 210-218, https://doi.org/10.1509/jmkg.2005.69.4.210

Hanna, R., A. Rohm., and V.L. Crittenden. 2011. "We're all connected: The power of the social media ecosystem." Business Horizons, $54 \quad$ (3): 265-273, doi:10.1016/j.bushor.2011.01.007.

Harridge-March, S., and S. Quinton. 2009. "Virtual snakes and ladders: social networks and the relationship marketing loyalty ladder." Marketing Review, 9 (2): 171-181, DOI 10.1362/146934709X442692.

Ho, C. 2014. "Consumer behavior on Facebook", EuroMed Journal of Business, 9 (3): 252 - 267, https://doi.org/10.1108/EMJB-12-2013-0057.

Hollebeek, L. 2011. "Demystifying customer brand engagement: Exploring the loyalty nexus." Journal of Marketing Management 27 (7/8): 785-807, DOI 10.1080/0267257X.2010.500132.

Hollebeek, L., and T. Chen. 2014. "Exploring positively- versus negatively-valenced brand engagement: a conceptual model." Journal of Product and Brand Management, 23 (1): 62-74, https://doi.org/10.1108/JPBM-06-2013-0332.

Hollebeek, L.D. 2013. "The customer engagement/value interface: An exploratory investigation." Australasian Marketing Journal, 21 (1): 17-24, https://doi.org/10.1016/j.ausmj.2012.08.006.

Hoyer, WD, R Chandy, M Dorotic, M Krafft and SS Singh (2010). Consumer cocreation in new product development. Journal of Service Research, 13(3), 283-296, https://doi.org/10.1177/1094670510375604.

Jin, Y., Fisher Liu, B. and Austin, L. 2014. "Examining the role of social media in effective crisis management: The effects of crisis origin, information form, and source on publics' crisis responses". Communication Research, 41 (1): 74-94, https://doi.org/10.1177/0093650211423918.

Kaplan A., and M. Haenlein. 2010. "Users of the world, unite! The challenges and opportunities of social media." Business Horizons, 53 (1): 59-68, https://doi.org/10.1016/j.bushor.2009.09.003.

Keeling, K., Keeling, D. and McGoldrick, P. 2011. "Retail relationships in a digital age" Journal of Business Research, 66 (7): 847-855, doi:10.1016/j.jbusres.2011.06.010.

Kietzmann, J. H., K. Hermkens., I. Mccarthy., P. Silvestre and S. Bruno. 2011. "Social Media? Get Serious! Understanding the functional building blocks of social media." Business Horizons, 54 (3): 241-251, https://doi.org/10.1016/j.bushor.2011.01.005.

Kizildag, M., M. Altin., O. Ozdemir., and I. Demirer. 2017. "What do we know about social media and firms' financial outcomes so far?" Journal of Hospitality and Tourism Technology, 8 (1) http://dx.doi.org/10.1108/JHTT-10-2016-0074.

Kozinets, R. 2009. Netnography: doing ethnographic research online. London: Sage. 
Kozinets, R. 2012. "Marketing Netnography: Promulgating a New Research Method." Methodological Innovations Online, 7 (1): 37-45, DOI: 10.4256/mio.2012.004.

Kozinets, R., K. De Valck., A. Wojnicki. and S. Wilner. 2010. "Networked narratives: Understanding word of mouth marketing in online communities." Journal of Marketing, 74 (2): 71-89, https://doi.org/10.1509/jmkg.74.2.71.

Kozinets, R.V. 2002. "The field behind the screen: using netnography for marketing research in online communities." Journal of Marketing Research, 39 (1): 61-72, https://doi.org/10.1509/jmkr.39.1.61.18935.

Kumar, V., L. Aksoy., B. Donkers., R. Venkatesan., T. Wiesel., and S. Tillmanns. 2010. "Undervalued or overvalued customers: Capturing total customer engagement value." Journal of Service Research, 13 (3): 297-310. doi:10.1177/1094670510375602.

Langer, R., \& S.C. Beckman. 2005. "Sensitive research topics: netnography revisited." Qualitative Market Research: an International Journal, 8 (2): 189-203, https://doi.org/10.1108/13522750510592454.

Lee, H., J. Han., and Y. Suh. 2014. "Gift or threat? An examination of voice of the customer: The case of MyStarbucksIdea.com." Electronic Commerce Research and Applications, 13 (3): 205-219, http://dx.doi.org/10.1016/j.elerap.2014.02.001.

Leeflang, P.S.H., P.C. Verhoef., P. Dahlström., and T. Freundt. 2014 "Challenges and solutions for marketing in a digital era." European Management Journal, 32 (1): 112, https://doi.org/10.1016/j.emj.2013.12.001.

Leppäniemi, M., H. Karjaluoto and H. Saarijärvi. 2016). "Customer perceived value, satisfaction, and loyalty: the role of willingness to share information." The International Review of Retail, Distribution and Consumer Research, 27 (2): 164-188, DOI: 10.1080/09593969.2016.1251482.

Lincoln, Y. S., and E.G. Guba. 1985. Naturalistic Inquiry. Beverly Hills, CA: Sage Publications.

Lipsman, A., G. Mudd., M. Rich., and S. Bruich. 2012. "The Power of "Like" How Brands Reach (and Influence) Fans Through Social-Media Marketing." Journal of Advertising Research, 52 (1): 40-52, DOI: 10.2501/JAR-52-1-040-052.

Lovett, M. J. and R. Staelin. 2016. "The Role of Paid, Earned, and Owned Media in Building Entertainment Brands: Reminding, Informing, and Enhancing Enjoyment", Marketing Science, 35 (1): 142-157, https://doi.org/10.1287/mksc.2015.0961.

Malhotra, A. 2012. "Defining Purpose and Meaning in Social Media." Vikalpa: The Journal For Decision Makers, 37 (4): 102-105.

Manchanda, P., G. Packard. and A. Pattabhitamaiah. 2012. "Social dollars: The economic impact of consumer participation in a firm-sponsored online community." Marketing Science Institute, MSI Report 11, 115.

Mangold, W.G. and D.J. Faulds. 2009. "Social media: The new hybrid element of the promotion mix." Business Horizons, 52 (4): 357-365, https://doi.org/10.1016/j.bushor.2009.03.002.

Miles, M., and M. Huberman. 1994. A qualitative data analysis: an expanded sourcebook, Thousand Oaks:Sage. 
Moorman, C. 2016. "The social media spend-impact disconnect", available at http://www.forbes.com/sites/christinemoorman/2016/02/16/the-social-mediaspendimpact-disconnect/\#1ebc377d417b (accessed on 16 February, 2016).

Muniz, A. and T. O'Guinn. "Brand community." Journal of Consumer Research, 27 (4): 412-432, DOI: 10.1086/319618.

O'Cass, A. and Viet Ngo, L. 2011. "Achieving customer satisfaction in services firms via branding capability and customer empowerment". Journal of Services Marketing, 25 (7): 489 - 496, https://doi.org/10.1108/08876041111173615.

Pansari, A., and V. Kumar. 2017. "Customer engagement: The construct, antecedents, and consequences." Journal of the Academy of Marketing Science, 25 (3): 294-311, DOI https://doi.org/10.1007/s11747-016-0485-6.

Park, H., and Y.K. Kim. 2014. "The role of social network websites in the consumerbrand relationship." Journal of Retailing and Consumer Services, 21 (4): 460-467, https://doi.org/10.1016/j.jretconser.2014.03.011.

Pereira, H.G., M.F. Salgueiro., and I. Mateus. 2014. "Say yes to Facebook and get your customers involved! Relationships in a world of social networks." Business Horizons, 57 (6): 695-702, http://dx.doi.org/10.1016/j.bushor.2014.07.001.

Pfeffer, J., T. Zorbach., and K. M. Carley. 2014. "Understanding online firestorms: Negative word-of-mouth dynamics in social media networks.” Journal of Marketing Communications, 20 (1-2): 117-128, DOI: 10.1080/13527266.2013.797778, p. 118.

Plé, L., and Chumpitaz C. 2010. "Not always co-creation: introducing interactional codestruction of value in service dominant logic". Journal of Services Marketing, 24 (6): 430 - 437, https://doi.org/10.1108/08876041011072546.

Pookulangara, S. and K. Koesler. 2011. "Cultural influence on consumers' usage of social networks and its' impact on online purchase intentions." Journal of Retailing and Consumer Services, 18 (4): 348-354, https://doi.org/10.1016/j.jretconser.2011.03. 003.

Porter, C., N. Donthu., W. MacElroy., and D. Wydra. 2011. "How to foster and sustain engagement in virtual communities." California Management Review, 53 (4): 80-110, https://doi.org/10.1525/cmr.2011.53.4.80.

Pöyry, E., P. Parvinen., and T. Malmivaara. 2013. "Can we get from liking to buying? Behavioral differences in hedonic and utilitarian Facebook usage." Electronic Commerce Research and Applications, 12 (4): 224-235, https://doi.org /10.1016/j.elerap.2013.01.003.

Queensland Government, https://www.business.qld.gov.au/running-business/marketingsales/marketing-promotion/online-marketing/social-media. Accessed on 4 October 2017.

Sashi, C. 2012. "Customer engagement, buyer-seller relationships, and social media". Management Decision, $50 \quad$ (2): $253 \quad-\quad 272, \quad$ https://doi.org/ $10.1108 / 00251741211203551$.

Schivinski, B., and D. Dabrowski. 2014 "The effect of social media communication on consumer perceptions of brands." Journal of Marketing Communications, 22 (2): 189214, DOI: $10.1080 / 13527266.2013 .871323$. 
Schultz, D.E., and J. Peltier. (2013). "Social media's slippery slope: challenges, opportunities and future research directions." Journal of Research in Interactive Marketing, 7 (2): 86-99, https://doi.org/10.1108/JRIM-12-2012-0054.

Schulze Horn I., T. Taros., S. Dirkes., L. Huer., M. Rose., R. Tietmeyer., and E. Constantinides. 2015. "Business Reputation and Social Media - A Primer on Threats and Responses." IDM Journal of Direct, Data and Digital Marketing Practice, 16 (3), DOI10.1057/dddmp.2015.1.

Shamhuyenhanzva, R.M., E. van Tonder, M. Roberts- Lombard and D. Hemsworth. 2016. "Factors influencing Generation Y consumers' perceptions of eWOM credibility: a study of the fast-food industry." The International Review of Retail,Distribution and Consumer Research, 26 (4): 435-455, DOI: 10.1080/09593969.2016.1170065.

Sheth, J. 2017. "Revitalizing relationship marketing." Journal of Services Marketing, 31 (1): 6-10, https://doi.org/10.1108/JSM-11-2016-0397.

Snow, T. 2012. "The power of social media". Fmcg, 18 (7); 14, Business Source Premier, EBSCOhost, viewed 4 February 2013.

Srinivasan, S., O. Rutz., and K. Pauwels. 2015. "Paths to and off purchase: Quantifying the impact of traditional marketing and online consumer activity", Journal of the Academy of Marketing Science, 44 (4): 1-14, https://doi.org/10.1007/s11747-0150431-z.

Stavros, C., M. Meng, K. Westberg., and F. Farrelly. 2014. "Understanding fan motivation for interacting on social media." Sport Management Review, 17 (4): 455 469, https://doi.org/10.1016/j.smr.2013.11.004.

Straus, A. and J. Corbin. 1990. Basics of qualitative research: Grounded theory procedures and techniques. Thousand Oaks, CA: Sage.

Tarnowski, J. 2011. "Social Studies.” Progressive Grocer, 90 (7): 85-130.

Tench, R. and B. Jones. 2015. "Social media: the Wild West of CSR communications", Social Responsibility Journal, 11 (2): 290 - 305, https://doi.org/10.1108/SRJ-122012-0157.

Thackeray, R., B.I. Neiger., C.L. Hanson, and J.F. McKenzie. 2008. "Enhancing promotional strategies within social marketing programs: use of Web 2.0 social media." Health Promotion Practice, 9 (4): 338-343, https://doi.org/ $10.1177 / 1524839908325335$.

Thornhill, M., K. Xie and Y. J. Lee. 2017. "Social media advertising in a competitive market: effects of earned and owned exposures on brand purchase." Journal of Hospitality and Tourism Technology, 8 (1): 87-100, https://doi.org/10.1108/JHTT-102016-0068.

Tsimonis, G., and S. Dimitriadis. 2014. "Brand strategies in social media." Marketing Intelligence \& Planning, 32 (3): 328-344, https://doi.org/10.1108/MIP-04-2013-0056.

Ul Islam, J., Z. Rahman. 2017. "The Impact of Online Brand Community Characteristics on Customer Engagement: A Solicitation of Stimulus-Organism-Response Theory." Telematics and Informatics, 34 (7), doi: http://dx.doi.org/10.1016/j.tele.2017.01.004.

Valerio Ureña, G.V., D. Herrera Murillo., N. Herrera Murillo and F.J. Martínez Garza. 2015. "Purposes of the communication between companies and their Facebook 
followers." Revista Latina de Comunicación Social, 70: 110-121. H ttp://www.revistalatinacs.org/070/paper/1037mx/07en.html DOI: 10.4185/RLCS2015-1037en

Van Dijk, J, G Antonides and N Schillewaert (2014). Effects of co-creation claim on consumer brand perceptions and behavioural intentions. International Journal of Consumer Studies, 38(1), 110-118, https://doi.org/10.1111/ijcs.12071.

van Doorn, J., K.N. Lemon., V. Mittal., S. Nass., D. Pick., P. Pirner, and P.C. Verhoef. 2010. "Customer Engagement Behavior: Theoretical Foundations and Research Directions." Journal of Service Research, 13 (3): 253-266, https://doi.org/10.1177/1094670510375599.

Vanden Bergh, B., M. Lee., E. Quilliam., and T. Hove. 2011. "The multidimensional nature and brand impact of user-generated ad parodies in social media." International Journal Of Advertising, 30 (1): 103-131, https://doi.org/10.2501/IJA-30-1-103-131.

Veloutsou, C. 2009. "Brands as relationship facilitators in consumer markets." Marketing Theory, 9 (1): 123-126, https://doi.org/10.1177/1470593108100068.

Verhoef, P., S. Beckers., and J. van Doorn. 2013. "Understand the Perils of Co-Creation." Harvard Business Review, 91 (9): 28-32.

Verhoef, P.C., W.J. Reinartz., and M. Krafft. 2010. "Customer Engagement as a New Perspective in Customer Management.” Journal of Service Research, 13 (3): 247-252, https://doi.org/10.1177/1094670510375461.

Vivek, S., S. Beatty., and R. Morgan. 2012. "Customer Engagement: Exploring Customer Relationships Beyond Purchase." Journal Of Marketing Theory \& Practice, 20 (2): 122-146, DOI: 10.2753/MTP1069-6679200201.

Yan, J. 2011. "Social media in branding: Fulfilling a need." Journal of Brand Management, 18 (9): 688-696, DOI https://doi.org/10.1057/bm.2011.19.

Zeithaml, V., L. Berry., and A. Parasuraman. 1996. "The Behavioral Consequences of Service Quality." Journal of Marketing, 60 (2): 31-46, DOI: 10.2307/1251929. 
Table 1: Customer reactions to company-initiated messages

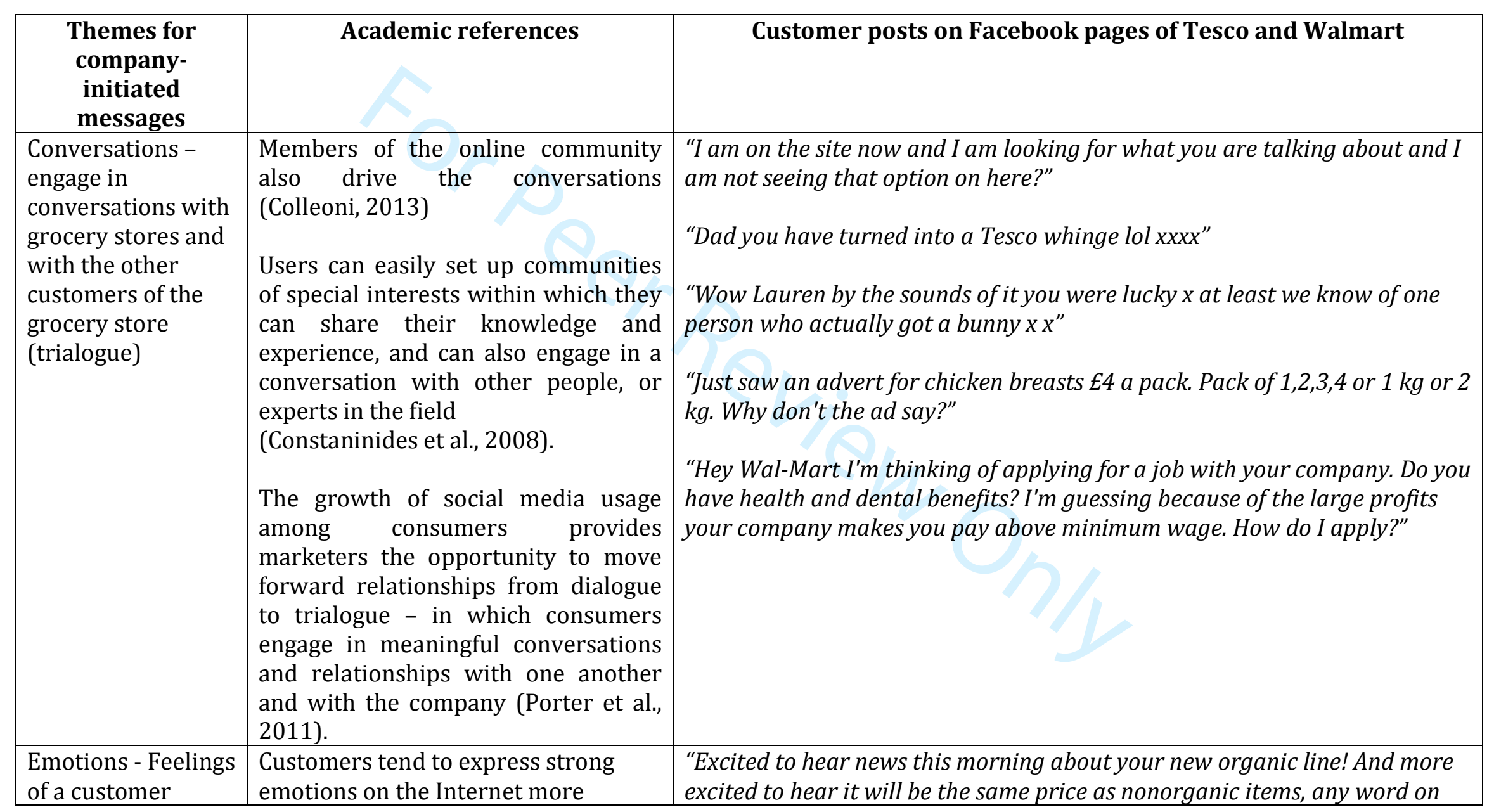




\begin{tabular}{|c|c|c|}
\hline towards a brand & $\begin{array}{l}\text { readily and easily owing to the } \\
\text { anonymity offered via this medium of } \\
\text { communication (Champoux et al., } \\
\text { 2012) } \\
\text { From an emotional perspective, } \\
\text { customer engagement may be } \\
\text { characterised by feelings of an } \\
\text { individual towards a brand (Vivek et } \\
\text { al., 2012), for e.g. a customer's level of } \\
\text { brand-related inspiration and/or } \\
\text { pride (Hollebeek, 2011). } \\
\text { Customers with strong emotional } \\
\text { bonds can become advocates for } \\
\text { sellers in peer-to-peer interactions } \\
\text { with other customers and non- } \\
\text { customers and play an important role } \\
\text { in the value adding process as co- } \\
\text { creators of value. (Sashi, 2012) }\end{array}$ & $\begin{array}{l}\text { when this will be in stores?" } \\
\text { "I have to say it eggcellent!!!" } \\
\text { "so you're trying to tell me that I can eat flowers now? Ya, nice try Walmart. } \\
\text { Feeling rather insulted that you're taking everyone for a ride with this } \\
\text { promo" } \\
\text { "Chinese Organics? I wouldn't trust Walmart to sell certified organics." }\end{array}$ \\
\hline $\begin{array}{l}\text { Co-creation of } \\
\text { value - } \\
\text { Level of perceived } \\
\text { value created in the } \\
\text { customer's mind } \\
\text { arising from } \\
\text { interactive, joint, } \\
\text { and/or }\end{array}$ & $\begin{array}{l}\text { Value co-creation is defined as the } \\
\text { mutual collaborative activities by } \\
\text { stakeholders participating in direct } \\
\text { interactions, aspiring to add to the } \\
\text { value that materializes for either one } \\
\text { or both parties (Grönroos,2012) } \\
\text { Co-creation happens when the }\end{array}$ & $\begin{array}{l}\text { "I'm having my first home delivery tonight for a pound. you've saved me } \\
\text { standing and queuing with } 2 \text { kids, arthritis and being pregnant with our } \\
\text { third. My cousin recommended how good your service is. Her husband works } \\
\text { for you too but she said your never late for your time slot so thought I'd give } \\
\text { it a whirl. I just used to love going to the supermarket but life makes it } \\
\text { harder these days." } \\
\text { "WalMart,you should sell Swiss muesli Familia in the stores vs online }\end{array}$ \\
\hline
\end{tabular}




\begin{tabular}{|c|c|c|}
\hline $\begin{array}{l}\text { personalised } \\
\text { activities for and } \\
\text { with stakeholders }\end{array}$ & $\begin{array}{l}\text { customer contributes through } \\
\text { spontaneous, discretionary } \\
\text { behaviours that personalise the } \\
\text { customer-to-brand experience (van } \\
\text { Doorn et al., 2010). }\end{array}$ & $\begin{array}{l}\text { only.Not many consumers are aware that there is better choice other than } \\
\text { the processesed Cheerios" } \\
\text { "The supplier is at fault not Tesco..." } \\
\text { "Purchase my \#SlowMeDown CD from my friends at Walmartand get a free } \\
\text { digital copy, too! xoxohttp://www.walmart.com/ip/34608038 } \\
\text { Purchase Sara Evans' "Slow Me Down" CD and get a free digital copy, too." }\end{array}$ \\
\hline $\begin{array}{l}\text { Co-destruction of } \\
\text { value - Co- } \\
\text { destruction of } \\
\text { value occurs during } \\
\text { interactions } \\
\text { between the } \\
\text { company and its } \\
\text { customers where } \\
\text { instead of creating } \\
\text { value for both } \\
\text { parties, value is } \\
\text { destroyed either } \\
\text { for all parties or for } \\
\text { one party }\end{array}$ & $\begin{array}{l}\text { Value co-destruction is defined "as an } \\
\text { interactional process between service } \\
\text { systems that results in a decline in at } \\
\text { least one of the systems' well-being" } \\
\text { (Plé and Chumpitaz Cáceres, 2010, p. } \\
431 \text { ). } \\
\text { Co-destruction denotes the joint } \\
\text { destruction, or impoverishment of } \\
\text { value by businesses and customers } \\
\text { (Echeverri \& Skålén, 2011). }\end{array}$ & $\begin{array}{l}\text { "Tesco huge fail. Again. Good luck. Why don't you employ proper staff to } \\
\text { deal with these things?" } \\
\text { "I've never known them to be very helpful past that. I surely know not to ask } \\
\text { where anything is located or for help at my local Walmart." } \\
\text { "No one would want their moms to be mistreated,no one would even want a } \\
\text { new mother pig to be mistreated either, right? Walmart's pork suppliers do } \\
\text { just that every day by using pork gestation crates. Demand Walmart stop } \\
\text { using these suppliers by buying your pork somewhere else!!!" } \\
\text { "Chicken with some amazing seasoning... carrots, new potatoes and suede... } \\
\text { all from Lidl! Thanks for asking! Chicken was on a deal and veg is cheaper } \\
\text { anyway" } \\
\text { "Everyone should do this country a favor and quit shopping at wal mart. } \\
\text { Start shopping somewhere that is willing to pay there employees a decent } \\
\text { wage give them benefits instead of the ceos putting all the money in there } \\
\text { pockets cause obviously they have more money then they will ever need and } \\
\text { there greed is disgusting please go away wal mart }\end{array}$ \\
\hline
\end{tabular}




\begin{tabular}{|l|l|}
\hline & $\begin{array}{l}\text { Looks like Tesco are getting desperate! You've lost my custom. I'll stick to } \\
\text { Aldi thanks. I can get a trolley full of gorgeous stuff for half the price of } \\
\text { Tesco and fruit and veg that doesn't go rotten within a day, if it isn't already } \\
\text { grotty when it arrives. " }\end{array}$ \\
\hline
\end{tabular}


Table 2: Customer-initiated messages

\begin{tabular}{|c|c|c|}
\hline $\begin{array}{c}\text { Themes for } \\
\text { customer-initiated } \\
\text { messages }\end{array}$ & Academic references & $\begin{array}{c}\text { Customer comments posted on Facebook pages of Tesco and } \\
\text { Walmart }\end{array}$ \\
\hline Customer complaints & $\begin{array}{l}\text { Consumers may post negative comments to } \\
\text { complain about a negative customer } \\
\text { experience with a brand (Jin, 2012) } \\
\text { Complaints are rife on social media platforms } \\
\text { and are a specific form of negative word of } \\
\text { mouth (Einwiller \& Steilen, 2015). } \\
\text { Most of the complaints posted on Facebook } \\
\text { are product or service related (Crecelius et al., } \\
2012 \text { ). }\end{array}$ & $\begin{array}{l}\text { Just been into tesco at Truro, what a fiasco getting a ticket to get out of } \\
\text { the car park. What a stupid, long winded, unfriendly system. Guess } \\
\text { what I won't be going back! } \\
409 \text { N marketplace blvd in Lansing Michigan only had two cashiers } \\
\text { working on a busy Friday night (today). Our ice cream melted while } \\
\text { waiting in line. The cashier in our line was extremely slow as well. The } \\
\text { lines went all the way to the clothes. I used to be a cashier at a } \\
\text { different store, scheduling so few cashiers on a busy weekend night is } \\
\text { poor management and poor customer service. }\end{array}$ \\
\hline Customer criticisms & $\begin{array}{l}\text { With web technologies such as blogs, it is } \\
\text { easy for brand critics to voice their frustration } \\
\text { (Fournier and Avery, 2011). } \\
\text { Repetitive and systematic customer attacks as } \\
\text { shitstorm, a term which denotes "emotional } \\
\text { and often irrational criticisms carried out by } \\
\text { many consumers. Rational negative opinions } \\
\text { usually form the basis for shitstorms, which } \\
\text { eventually grow through irrational and } \\
\text { assertive content added by other dissatisfied }\end{array}$ & $\begin{array}{l}\text { Is anyone else getting the impression that the right hand does not know } \\
\text { what the left hand is doing, as far as Tesco is concerned, and this } \\
\text { thread? They appear to be answering random queries and points, and } \\
\text { NO-ONE appear to know the answer to Angela's question! Tesco } \\
\text { clearly do not KNOW what is in the food they are selling us. Appalling. } \\
\text { I think it's absolutely disgusting practice to sell ONLY halal meat, that } \\
\text { non Muslim people now have to eat meat slaughtered with Islamic } \\
\text { prayers. As a Christian I do not want to eat meat blessed in another } \\
\text { religion! I hope you're also aware of the barbaric nature in which the } \\
\text { animal is slaughtered, it gets it's throat slit without stunning. The }\end{array}$ \\
\hline
\end{tabular}




\begin{tabular}{|c|c|c|}
\hline & users." (Schulze Horn et al., 2015, p.4). & $\begin{array}{l}\text { animal feels every centimetre of the cut. It's wrong! It's cruel and it's } \\
\text { appeasement of a minority over the wishes of the majority who do not } \\
\text { want to eat this filth. You have lost my custom. }\end{array}$ \\
\hline Express satisfaction & $\begin{array}{l}\text { A customer's overall evaluation of the } \\
\text { performance of an offering to date } \\
\text { (Gustaffson et al., 2005). }\end{array}$ & $\begin{array}{l}\text { I have been collecting the vouchers for the Thomas offer, Last week I } \\
\text { purchased the knife block. The large santou knife would not fit. } \\
\text { Returned block to stock with knife and the assistant Darren was very } \\
\text { helpful. Exchanged block. Knife fitted .One happy customer.. } \\
\text { Thank you so much for donating close code product toFeeding } \\
\text { America Tampa Bay and for even taking your boxes back. Really } \\
\text { grateful. \#farmergratitude }\end{array}$ \\
\hline Post queries & $\begin{array}{l}\text { Customers connect to a Facebook brand page } \\
\text { because they want to get information about } \\
\text { the brand (Pereira et al., 2014) }\end{array}$ & $\begin{array}{l}\text { I used to buy a lot of Value items, many of which seem to be no longer } \\
\text { available. Is there an up to date list of what is available, please? } \\
\text { which stores will you be selling the Wild Oats products in? we } \\
\text { desperately need these in our town! }\end{array}$ \\
\hline
\end{tabular}




\begin{tabular}{|c|c|c|}
\hline & Parasnis, 2011) & \\
\hline Customer suggestions & $\begin{array}{l}\text { A form of customer engagement behaviour is } \\
\text { when customers make suggestions as to how } \\
\text { to enhance the customer experience (van } \\
\text { Doorn et al., 2010). } \\
\text { Customers at times make suggestions to the } \\
\text { company and these suggestions turn } \\
\text { customers into co-creators of value for the } \\
\text { organisation (O'Cass \& Viet Ngo, 2011) }\end{array}$ & $\begin{array}{l}\text { But as for bogof, they don't benefit everyone. We are a family of six so } \\
\text { get through a lot, but people on their own, even storing food correctly, } \\
\text { are likely to waste some. Half pricing things instead of offering bogof } \\
\text { would do a lot to reduce food waste and keep customers happy. } \\
\text { Add a stores in Princeton and in wolf city and in Anna Texas and in } \\
\text { surf side beac and in Galveston and in the city of west Texas }\end{array}$ \\
\hline
\end{tabular}


Table 3: Customer posts on Facebook pages of Tesco and Walmart

\begin{tabular}{|c|c|}
\hline Occurrences of Behavioural Engagement & Customer's comment posted on Facebook pages of Tesco and Walmart \\
\hline Request for more information & "What type of baby clothes you have?? I need some new ones." \\
\hline Seeking entertainment & "this game is so fun ahahaha" \\
\hline Request for additional incentives & "B [sic], Do i [sic] get a free pack ?[sic]" \\
\hline $\mathrm{C} 2 \mathrm{C}$ (customer to customer) conversations & "No golden egg for me Frazer, unfortunately. I'm going to stay so skinny, ha ha! [sic]" \\
\hline Giving advice to other customers & $\begin{array}{l}\text { "I found a better way for them to last longer, put them in a bowl of water and a cup of vinegar and } \\
\text { soak for } 10 \text { min. and then rinse off and put in refrigerator. They stay fresh LONGER AND THEY } \\
\text { ARE CLEAN AND PESTICIDE FREE!!!! [sic]" }\end{array}$ \\
\hline Criticising other customers, & $\begin{array}{l}\text { "Why do people like wal-mart [sic] on facebook [sic] and then get on here and just gripe? Get a } \\
\text { life people. There are many issues in the world bigger than the wages wal-mart [sic] pays their } \\
\text { associates." }\end{array}$ \\
\hline Helping other customers & "click on the link provided (it worked for me) and search on that site" \\
\hline Complaining & $\begin{array}{l}\text { "Well would have had lamb but not open today, also [sic] have 25quids [sic] worth of 5pound off } \\
\text { vouchers that run out today,so [sic] thanks tesco i [sic] can afford to lose all that money. Thanks } \\
\text { once again (NOT)!!! [sic]" }\end{array}$ \\
\hline Criticising & $\begin{array}{l}\text { "What a bunch of hog wash [sic] !!!! Walmart you are one of the hugest reasons the working poor } \\
\text { stay poor!!!! Shame on u!!! Pay living wages and give health benefits and then you can make } \\
\text { claims like this!!!!" }\end{array}$ \\
\hline Providing information about competitors & $\begin{array}{l}\text { "Wouldn't shop at tesco [sic] ever again....quality of food has dropped! Rather shop at morrisons } \\
\text { [sic] now. At least they stock FRESH fruit n veg [sic]." }\end{array}$ \\
\hline Warning customers against a product/service & $\begin{array}{l}\text { "I recommend getting your ham just about anywhere other than Walmart. The pigs in Walmart's } \\
\text { supply chain are kept in gestation crates for most of their lives." }\end{array}$ \\
\hline Asking to boycott a store & $\begin{array}{l}\text { "It's sad that I live in American [sic] and get blocked for voicing my opinion. You lost a customer. } \\
\text { I will be boycotting all walmarts. I know this will not effect [sic] your financial state but I will } \\
\text { spread the word! I know a lot of people who value my opinion. I will spend money else where [sic] }\end{array}$ \\
\hline
\end{tabular}


C2B conversations: customer query related, customer query unrelated, entertainment, incentive, information, and participation

Company initiated messages 17 8
$\mathrm{C} 2 \mathrm{C}$ conversations: conversation.

customers as co-helpers,

criticising other customers,

support to other customers,

Emotion: enthusiasm, humour. sarcasm and skepticism

Negative and unfavourable

actions: complaint, criticism.

information about competitors,

negative customer referral, and retaliation

Positive and favourable actions:

customer referral, customer

suggestions, customer defending

the company, customer

defending employees of the

company and finally promotion by customer

\section{Relationship building: customer} satisfaction and customer loyalty Walmart.

(Source: developed by the authors)
Complaint by customer Reactions of other customers: Providing support, Offering help and advice, criticising, mixed responses and defending the company

Criticism by customer expression of gratitude
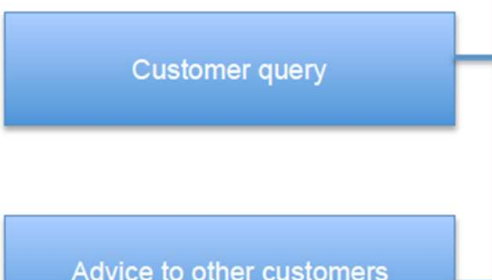

Advice to other customers

Suggestions by customers

Fig. 1. Customer reactions to messages posted on Facebook pages of Tesco and 


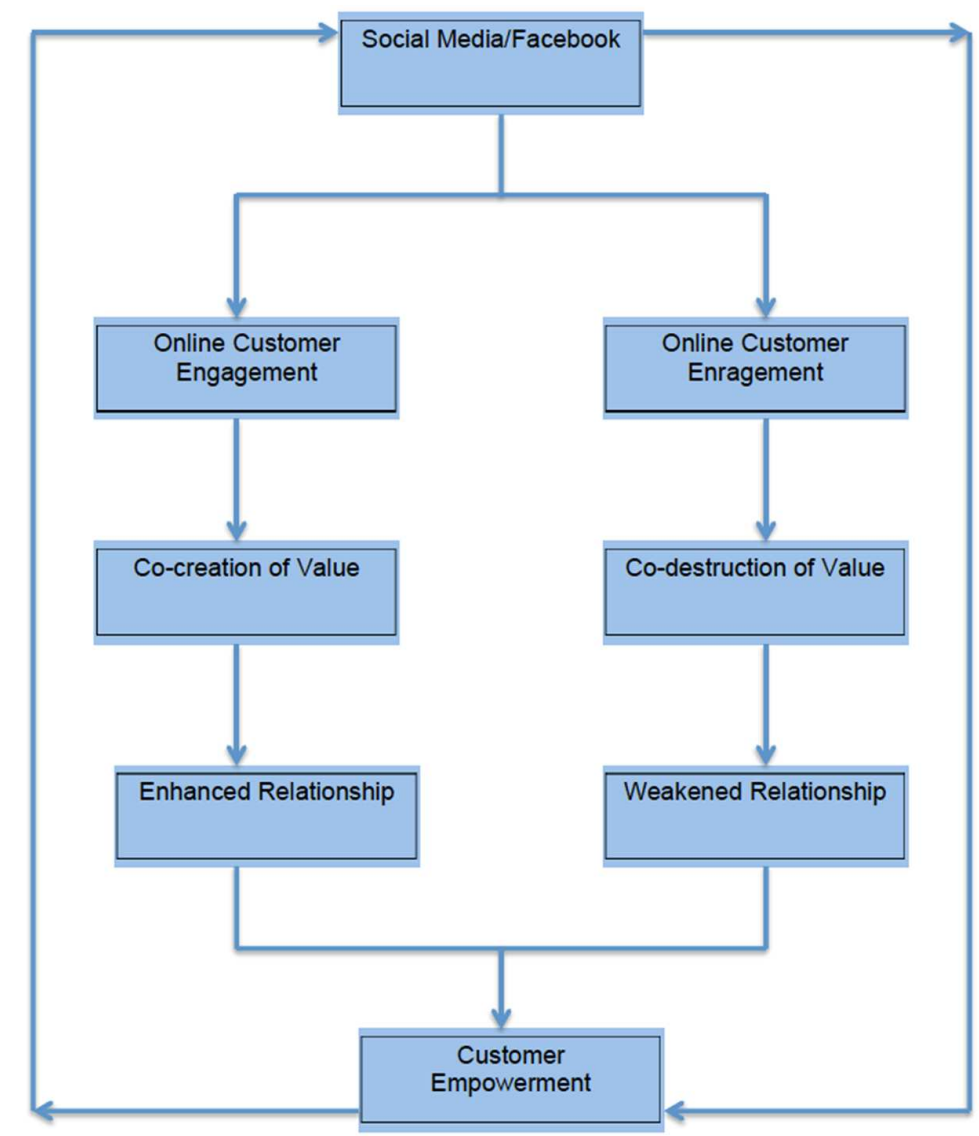

Fig. 2. Creation and Destruction of value on Facebook pages of Tesco and Walmart. (Source: developed by the authors) 


\begin{tabular}{|c|c|}
\hline \multicolumn{2}{|c|}{ Reviewer 1} \\
\hline Comments & Response \\
\hline $\begin{array}{l}\text { Thank you for making the changes as } \\
\text { suggested. This is an important area of } \\
\text { growth and this paper addresses this } \\
\text { gap well. }\end{array}$ & Thank you. \\
\hline \multicolumn{2}{|c|}{ Reviewer 2} \\
\hline Comments & Response \\
\hline $\begin{array}{l}\text { The paper was improved. However, } \\
\text { some issues should be addressed prior } \\
\text { to accepting the manuscript for } \\
\text { publication. }\end{array}$ & Thank you for the suggestions. \\
\hline $\begin{array}{l}\text { Please include the section title } \\
\text { "Literature review". }\end{array}$ & The section title was added. See p. 3 \\
\hline $\begin{array}{l}\text { Customer empowerment and } \\
\text { relationship marketing must be } \\
\text { defined when presented in literature } \\
\text { review. }\end{array}$ & $\begin{array}{l}\text { The definitions have been added. For } \\
\text { customer empowerment see p. } 3 \text { and } \\
\text { for relationship marketing see p. } 4\end{array}$ \\
\hline $\begin{array}{l}\text { Figure } 1 \text { must use a letter size that is } \\
\text { readable which is not the case. }\end{array}$ & $\begin{array}{l}\text { The letter size has been increased. See } \\
\text { Figure } 1\end{array}$ \\
\hline $\begin{array}{l}\text { [p.11: 6-7] How do you justify that } \\
\text { when customers are engaged } \\
\text { utilitarian and hedonic value increase? } \\
\text { What are the evidences that you } \\
\text { collect? Please, clarify. }\end{array}$ & $\begin{array}{l}\text { Two paragraphs have been included to } \\
\text { support these claims. See p. } 11 \text {. }\end{array}$ \\
\hline Good luck. & $\begin{array}{l}\text { Thank you. We are grateful for the } \\
\text { reviewers' feedback and believe the } \\
\text { changes we have made have further } \\
\text { improved the paper. We believe the } \\
\text { paper is now ready for publication but } \\
\text { if further changes are required then we } \\
\text { are happy to address. }\end{array}$ \\
\hline
\end{tabular}

